\title{
Innovative approaches to photonics workforce development
}

\section{Dominique Foley Wilson}

Dominique Foley Wilson, "Innovative approaches to photonics workforce development," Proc. SPIE 9664, Ninth International Topical Meeting on Education and Training in Optics and Photonics, 966418 (24 October 2005); doi: $10.1117 / 12.2207777$

Event: Ninth International Topical Meeting on Education and Training in Optics and Photonics, 2005, Marseille, France 
This paper is freely available as a resource for the optics and photonics education community.

Ref ETOP092

Innovative Approaches to Photonics Workforce Development

Dominique Foley Wilson, Consultant, Laboratory Critical Skills Development

\begin{abstract}
Photonics as an enabling technology offers a plethora of perspectives from which to approach workforce development. Hands-on, inquiry-based curriculum and activities have been developed that attract and inspire students from middle school through post-secondary. The curricula are cross-cutting across multiple disciplines, demographics, and ages. Articulation between levels has proven an essential element of success. Learn how industry, government, academia, parents, students, professional societies collaborate to further opportunities for in photonics and microtechnology.
\end{abstract}

